\title{
PERENCANAAN KESEIMBANGAN LINTASAN UNTUK MENINGKATKAN EFFISIENSI KERJA DENGAN MENGGUNAKAN METODE RPW
}

\section{Teguh Baroto $^{1}$, Wahyu Eni Maryati ${ }^{2}$}

\begin{abstract}
This rescarch aims to orrange a balance production line to improve work efficiency to rice production output. This line balancing planning, we use Rank Position Weight ( RPW ).

Using operation time data in every work station and also precedence diagram based on the shoes making process could be found elements/operation group involving a work station. With 3 cycles time such as 100,150 ang 160 seconds could be found a cycle time 150 seconds result minimum operation grouping of balance delay. From this planning could be concluded that there were 10 work stations with production output 168 part of shoes of day.

After line balancing design, could be got minimum balance delay $5,99 \%$ lower than the old one $(60,56 \%)$ and efficiency $94,01 \%$ that the best efficiency if compared with the begening condition $(39,44)$.
\end{abstract}

Key Words : efficiency, planning, planning

\section{PENDAHULUAN}

PT. Artisan I. Malang memproduksi berbagai jenis kerajinan kulit, diantaranya tas kulit, sabuk kulit, sepatu kulit. Sedangkan proses produksi dari produk yang dihasilkan dimulai dari barang mentah yang berbentuk lembaran kulit kemudian diproses sesuai dengan bentuk yang diinginkan. Produk yang dihasilkan oleh perusahaan ini dipasarkan keluar negeri diantaranya Australia, Amerika dan negara Asia lainnya.

Hasil pengamatan selama survey perusahaan menunjukkan, ada beberapa ketidak effesienan yang terjadi selama proses produksi seperti terjadinya penumpukan barang di salah satu stasuin kerja, sementara di stasiun kerja lainnya banyak tenaga kerja yang menganggur, karena menunggu barang setengah jadi dari stasuin kerja sebelumnya. Contohnya pada stasiun penyemiran banyak barang yang sudah jadi sepatu tetapi belum disemir, di stasiun pasang lening banyak tenaga kerja menganggur karena menunggu barang dari stasiun pemotongan lenning. Penumpukan barang dan banyaknya tenaga kerja menganggur akan menyebabkan proses produksi menjadi tidak efektif dan tidak produktif, dan secara otomatis akan menambah beban biaya produksi dan juga mengurangi out put produksi.

\section{Banyak metode yang bisa digunakan} dalam menyelesaikan permasalahan diatas, diantaranya adalah metode Line Balancing yang tujuannya adalah untuk meningkatkan efisiensi kerja , mengurangi waktu menganggur, meningkatkan produktifitas perusahaan, menyeimbangkan aliran proses produksi.

Penelitian ini bertujuan untuk menerapkan sebuah metode Line Balancing yaitu Rank Positional Weight (RPW) untuk merencanakan keseimbangan lintasan produksi dengan jalan mengatur dan mengalokasikan masing-masing 
elemen kerja ke beberapa stasiun kerja guna meminimalkan Balance delay dan Effisiensi dari stasiun - stasiun kerja.

\section{TINJAUAN PUSTAKA}

\section{Keseimbangan Lintasan dengan Rank Positional Waight}

\section{Metode "Rank Positional Weight"} yang biasa disebut dengan metode HelgessonBirnie merupakan salah satu metode Heuristic yang ada. Langkah-langkah pemecahan masalah dengan metode Metode Rank Positional Weight ( RPW) adalah sebagai berikut : (Elsayed, 1994:360)

a. Membuat precedence diagram

Precedence diagram merupakan gambaran secara grafis dari suatu urutan proses operasi serta ketergantungannya kepada operasi lainnya.

Adapun tanda-tanda yang dipakai adalah sebagai berikut :

- Simbol lingkaran dengan huruf atau nomor didalam untuk mempermudah identifikasi dari suatu proses operasi

- Simbol panah menunjukkan ketergantungan dari urutan proses operasi. Operasi pada pangkal panah berarti mandahului operasi kerja yang ada pada ujung panah.

- Angka diatas symbol adalah waktu standar yang diperlukan untuk menyelesaikan setiap operasi.

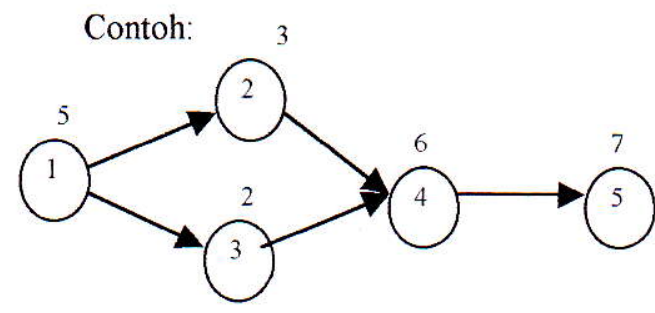

b. Membuat Precedence Matriks

Precedence matriks berisi informasi yang sama dengan precedence diagram tetapi dalam precedence matrik hubungan antara elemen-elemen atau operasi-operasi dengan angka 0,1 , dan -1 .

Keterangan :

- 0 jika tidak ada hubungan antara opersi satu dengan operasi lainnya

- 1 jika operasi kerja tersebut mengikuti operasi yang mendahului

- -1 jika operas kerja tersebut mendahului operasi kerja yang lain

c. Menghitung bobot posisi masing-masing operasi berdasarkan precedence matrik

d. Membuat urutan berdasarkan pada bobot posisi, urutan pertama dengan bobot posisi terbesar dan yang terakhir adalah yang paling kecil. Jika ditemui dua elemen atau lebih yang mempunyai bobot sama, bisa diurut sesuai dengan urutan mereka dalam daftar.

e. Menetapkan waktu siklus berdasarkan out put yang ditetapkan (out put terkecil).

f. Menempatkan operasi-operasi dalam stasiun kerja dengan cara sebagai berikut :

- Menempatkan operasi elemen-elemen kerja dengan bobot posisi terbesar pada stasiun kerja pertama

- Menghitung selisih waktu operasi dengan waktu siklus (yang membatasi lamanya operasi) secara kumulatif.

- Operasi dengan urutan bobot posisi terbesar selanjutnya ditempatkan pada urutan berikutnya dan kemudian dilakukan pemeriksaan berikut: 
- Precedence matrik hanya elemenelemen yang pendahuluannya telah dipilih dapat diperhitungkan.

- Waktu operasi dari elemen-elemen kerja harus sama atau lebih dari hasil perhitungan sebelumnya (ketentuan $\mathrm{f}$ kedua). Apabila kondisi $((\bullet)$ pertama dan $((\bullet)$ kedua $)$ ditemukan selanjutnya operasi tersebut ditetapkan pada stasiun kerja pertama $((\bullet)$ pertama). Untuk selanjutnya ketentuan $\mathrm{f}$ kedua dan ketiga diulang untuk operasi dengan bobot posisi terendah.

g. Ketentuan $\mathrm{f}$ kedua dan ketiga dilanjutkan sampai tidak ada perbedaan waktu antar jumlah waktu operasi yang telah ditetapkan pada stasiun kerja dengan waktu siklus.

h. Stasiun kerja kedua dimulai dengan memilih elemen yang mempunyai rangking terendah atau membuat bobot posisi paling tinggi yang belum terpilih (tidak memenuhi ketentuan ( $\mathrm{f}$ ketiga (•) kedua).

Ketentuan "f" kedua, ketiga , keempat dan kelima dilanjutkan sampai semua elemen kerja terpilih atau teralokasi pada stasiun kerja.

\section{Balance Delay}

Ukuran ketidakseimbangan dalam suatu lintasan produksi yang merupakan jumlah waktu menganggur pada lintsan yang dinyatakan sebagai prosentase pemakaian waktu pada lintasan yang dirumuskan sebagai berikut :

$$
D=\left[\frac{n . c-\sum_{i=1}^{N} t_{i}}{n \cdot c}\right] \times 100 \%
$$

dimana: $\mathrm{n} \quad=$ jumlah stasiun kerja c = waktu siklus terbesar dalam stasiun kerja

$\sum \mathrm{t}_{\mathrm{i}}=$ jumlah waktu operasi dari semua operasi

$t_{i} \quad=$ waktu operasi $(I=1,2,3, \ldots, n)$

D = balance delay $(\%)$

\section{Efisiensi System}

Besarnya efisiensi dari setiap alokasi pada stasiun kerja dinyatakan dalam bentuk prosentase yang diperoleh dari rumus :

$$
\pi=100 \%-\mathrm{D}
$$

\section{Out put produksi}

Out put ialah digunakan untuk siklus selama pereode waktu produksi rumusnya :

$$
O s=\frac{1}{W s}
$$

dimana Ws $=$ Waktu siklus terbesar

\section{Waktu Siklus Stasiun Kerja}

Waktu siklus merupakan waktu yang dibutuhkan oleh lintasan produksi untuk menghasilkan 1 unit produk. Waktu siklus harus sama dengan atau lebih besar daripada waktu operasi terbesar. Ini dimaksudkan untuk menghindari terjadinya "bottle neck" (kemacetan) yang disebabkan oleh operasi dengan waktu terbesar.

Secara matematis waktu siklus bisa dirumuskan :

$$
\mathrm{T}_{\mathrm{i} \max } \leq \mathrm{C}_{\text {optimal }} \leq \mathrm{P} / \mathrm{Q}
$$

Keterangan :

$\mathrm{T}_{\mathrm{imax}}=$ waktu operasi terbesar

$\mathrm{C}_{\text {optimal }}=$ waktu siklus dengan balance delay seminimal mungkin

$\mathrm{P} \quad=$ periode waktu yaitu $7 \mathrm{jam} / \mathrm{hari}$

$\mathrm{Q}=$ jumlah produk (output) yang

dibutuhkan selama periode 


\section{METODOLOGI PENELITIAN}

\section{Pengumpulan data}

Data yang digunakan dalam penelitian ini adalah data waktu operasi dari setiap stasiun kerja, data performance rating dari operator pada masing-masing stasiun kerja, data allowance time, aliran proses produksi untuk pembuatan sepatu, jumlah stasiun kerja dan tenaga kerja yang ada sekarang serta data gaji tenaga kerja.

\section{Pengolahan Data}

Tahap-tahap pengolahan data meliputi :

1. Tes keseragaman Data, untuk mengetahui apakah data waktu yang dikumpulkan seragam atau tidak, jika ada data yang ekstrim (keluar dari batas pengendali) maka data tersebut dibuang.

2. Tes kecukupan data, untuk mengetahui apakah data waktu yang dikumpulkan (N) sudah mencukupi ataukah belum. Data dikatakan cukup jika N' (jumlah data yang seharusnya diambil) kurang dari sama dengan jumlah data yang dikumpulkan $(\mathrm{N})$.

3. Menghitung waktu normal dan waktu standart pada tiap stasiun kerja. Untuk mendapatkan waktu normal maka harus dikumpulkan data performance rating operator (p) dan selanjutnya waktu normal dihitung dengan rumus $\mathbf{W n}=$ Waktu pengamatan rata-rata x p. Dan selanjutnya waktu standart dihitung berdasrakan waktu normal dengan memasukkan faktor allowance (kelonggaran) diman rumus perhitungan waktu standard adalah : Waktu standard = waktu normal

$\mathbf{x} \frac{100 \%}{100 \%-\text { allowence }(\%))}$

4. Membuat precedence diagram, untuk mengetahui urutan operasi dari setiap elemen-elemen kerja

5. Merencanakan keseimbangan lintasan dengan metode RPW, dengan menggunakan data waktu operasi di tiap stasiun kerja dan precedence diagram. Dengan mencoba beberapa waktu siklus akan diperoleh beberapa solusi lintasan produksi yang baru dengan balance delay dan effisiensi yang berbeda-beda. Dan untuk mempermudah dalam pengerjaan maka digunakan Sofware Quantitative System (QS).

\section{Perbandingan Lintasan Produksi Sebelum dan Sesudah}

Dari hasil diatas, selanjutnya dilakukan perbandingan antara hasil keseimbangan lintasan (metode RPW) dengan keadaan sebelum dilakukan perencanaan. Kriteria yang digunakan adalah: Balance dellay dan Out put Produksi .

\section{HASIL DAN PEMBAHASAN}

Urutan proses produksi pada pembuatan produk ini akan dijelaskan melalui tabel berikut ini:

Tabel 1. Urutan Proses Produksi

\begin{tabular}{|c|c|c|}
\hline No & KODE & $\begin{array}{r}\text { OPERASI } \\
\end{array}$ \\
\hline 1 & $0-01$ & Pengemalan \\
\hline 2 & $0-02$ & $\begin{array}{l}\text { Pemotongan Bahan Kulit sesuai } \\
\text { dengan pola }\end{array}$ \\
\hline 3 & $0-03$ & Penyesetan \\
\hline 4 & $0-04$ & Pengleman hasil seset \\
\hline 5 & $0-05$ & Penglipatan bagian seset \\
\hline 6 & $0-06$ & Trap model \\
\hline 7 & $0-07$ & Pengemalan (linning dan Keras) \\
\hline 8 & $0-08$ & $\begin{array}{l}\text { Memotong Lining (linning dan } \\
\text { Keras) sesuai dengan pola }\end{array}$ \\
\hline 9 & $0-09$ & $\begin{array}{l}\text { Memberi lem pada lining yang } \\
\text { akan diseset }\end{array}$ \\
\hline
\end{tabular}




\begin{tabular}{|c|c|l|}
\hline NO & KODE & \multicolumn{1}{|c|}{ OPERASI } \\
\hline 10 & $0-10$ & Pemasangan lining \\
\hline 11 & $0-11$ & Pengetrapan \\
\hline 12 & $0-12$ & Penjahitan \\
\hline 13 & $0-13$ & Di beri besi (lubang tali) \\
\hline 14 & $1-01$ & Pemeriksaan \\
\hline 15 & $0-14$ & Pengemalan in sole \\
\hline 16 & $0-15$ & Lem tepian kap \\
\hline 17 & $0-16$ & Pemotongan in sole \\
\hline 18 & $0-17$ & Pengeleman in sole \\
\hline 19 & $0-18$ & Pemasangan in sole \\
\hline 20 & $0-19$ & Pencetakan lasting \\
\hline 21 & $0-20$ & Amplas tepian hasil lasting \\
\hline 22 & $0-21$ & Amplas out sole \\
\hline 23 & $0-22$ & Pengeleman out sole \\
\hline 24 & $0-23$ & Pemasangan out sole \\
\hline 25 & $0-24$ & Pengepresan \\
\hline 26 & $1-02$ & Pemeriksaan \\
\hline 27 & $0-25$ & Pembersihan lem dan noda \\
\hline 28 & $0-26$ & Penyemiran/make up \\
\hline 29 & $0-27$ & Pengeleman in sole dalam \\
\hline 30 & $0-28$ & Pengemalan sok lining \\
\hline 31 & $0-29$ & Pemotongan bahan sok lining \\
\hline 32 & $0-30$ & Pengeleman bahan sok lining \\
\hline 33 & $0-31$ & Pemasangan sok lining \\
\hline 34 & $1-03$ & Pemeriksaan \\
\hline 35 & $0-32$ & Pengepakan \\
\hline & & \\
\hline
\end{tabular}

Tenaga kerja yang terlibat dalam Proses

\section{Produksi}

Adapun jumlah tenaga kerja yang terlibat dalam proses produksi adalah sebanyak 35 Orang dan upah tenaga kerja yang terlibat dalam proses produksi adalah sebesar Rp.15.000/hari untuk setiap tenaga kerja.

\section{Perhitungan Waktu Normal dan Waktu Standart Pada Masing-Masing Stasiun Kerja}

Selanjutnya berdasarkan data waktu yang telah dikumpulkan pada masing-masing stasiun kerja dilakukan uji keseragaman dan uji kecukupan data. Setelah semua data cukup dan seragam maka dilakukan perhitungan waktu normal dan waktu standard. Hasil perhitungan tersebut sebagai berikut :

\section{Tabel 2. Hasil perhitungan waktu normal}

\begin{tabular}{|c|c|c|c|}
\hline $\begin{array}{c}\text { KODE } \\
\text { OPERASI }\end{array}$ & $\begin{array}{c}\text { WAKTU } \\
\text { SIKLUS } \\
\text { (detik) }\end{array}$ & $\begin{array}{c}\text { PENYE- } \\
\text { SUAIAN (P) }\end{array}$ & $\begin{array}{c}\text { WAKTU } \\
\text { NORMAL } \\
\text { (detik) }\end{array}$ \\
\hline $0-01$ & 29.4 & 1.16 & 34.10 \\
\hline $0-02$ & 59.9 & 1.13 & 67.69 \\
\hline $0-03$ & 79.7 & 1.19 & 94.84 \\
\hline $0-04$ & 49.9 & 1.16 & 57.88 \\
\hline $0-05$ & 59.9 & 1.11 & 66.49 \\
\hline $0-06$ & 29.8 & 1.19 & 35.46 \\
\hline $0-07$ & 12.2 & 1.16 & 14.15 \\
\hline $0-08$ & 28.3 & 1.16 & 32.83 \\
\hline $0-09$ & 14.7 & 1.13 & 16.61 \\
\hline $0-10$ & 29.5 & 1.16 & 34.22 \\
\hline $0-11$ & 29.3 & 1.13 & 33.11 \\
\hline $0-12$ & 79.8 & 1.18 & 94.16 \\
\hline $0-13$ & 59.7 & 1.11 & 66.27 \\
\hline $1-01$ & 14.3 & 1.12 & 17.16 \\
\hline $0-14$ & 14.3 & 1.17 & 16.73 \\
\hline $0-15$ & 20.3 & 1.16 & 23.55 \\
\hline $0-16$ & 6.8 & 1.13 & 7.68 \\
\hline $0-17$ & 12.2 & 1.16 & 14.15 \\
\hline $0-18$ & 12.2 & 1.15 & 14.03 \\
\hline $0-19$ & 28.5 & 1.11 & 31.63 \\
\hline $0-20$ & 28.9 & 1.11 & 32.08 \\
\hline $0-21$ & 40.3 & 1.13 & 45.54 \\
\hline $0-22$ & 59.9 & 1.16 & 69.48 \\
\hline $0-23$ & 40.4 & 1.19 & 48.08 \\
\hline $0-24$ & 20 & 1.16 & 23.2 \\
\hline $1-02$ & 16.9 & 1.2 & 20.28 \\
\hline $0-25$ & 25.6 & 1.21 & 30.98 \\
\hline $0-26$ & 19.4 & 1.19 & 23.09 \\
\hline $0-27$ & 21.2 & 1.13 & 23.96 \\
\hline $0-28$ & 15.6 & 1.16 & 18.09 \\
\hline $0-29$ & 40.3 & 1.14 & 45.94 \\
\hline $0-30$ & 20.1 & 1.16 & 23.32 \\
\hline $0-31$ & 40.4 & 1.2 & 48.48 \\
\hline $1-03$ & 14.3 & 1.16 & 16.59 \\
\hline $0-32$ & 9.4 & 1.16 & 10.90 \\
\hline
\end{tabular}

Tabel 3. Hasil perhitungan standard

\begin{tabular}{|c|c|c|c|}
\hline $\begin{array}{c}\text { KODE } \\
\text { OPERASI }\end{array}$ & $\begin{array}{c}\text { W. } \\
\text { NORMAL } \\
\text { (detik) }\end{array}$ & $\begin{array}{c}\text { ALLOW } \\
\text { ENCE } \\
\text { (\%) }\end{array}$ & $\begin{array}{c}\text { W.STAN } \\
\text { DART } \\
\text { (detik) }\end{array}$ \\
\hline $0-01$ & 34.10 & 0.15 & 40.12 \\
\hline $0-02$ & 67.69 & 0.15 & 79.63 \\
\hline $0-03$ & 94.84 & 0.15 & 111.57 \\
\hline $0-04$ & 57.88 & 0.15 & 68.09 \\
\hline $0-05$ & 66.49 & 0.15 & 78.22 \\
\hline $0-06$ & 35.46 & 0.15 & 41.72 \\
\hline $0-07$ & 14.15 & 0.15 & 16.65 \\
\hline $0-08$ & 32.83 & 0.15 & 38.62 \\
\hline $0-09$ & 16.61 & 0.15 & 19.54 \\
\hline $0-10$ & 34.22 & 0.15 & 40.26 \\
\hline $0-11$ & 33.11 & 0.15 & 38.95 \\
\hline $0-12$ & 94.16 & 0.15 & 110.78 \\
\hline $0-13$ & 66.27 & 0.15 & 77.96 \\
\hline $1-01$ & 17.16 & 0.15 & 20.19 \\
\hline $0-14$ & 16.73 & 0.15 & 19.68 \\
\hline $0-15$ & 23.55 & 0.15 & 27.70 \\
\hline $0-16$ & 7.68 & 0.15 & 9.03 \\
\hline $0-17$ & 14.15 & 0.15 & 16.65 \\
\hline $0-18$ & 14.03 & 0.15 & 16.50 \\
\hline
\end{tabular}




\begin{tabular}{|c|c|c|c|}
\hline $\begin{array}{c}\text { KODE } \\
\text { OPERASI }\end{array}$ & $\begin{array}{c}\text { W. } \\
\text { NORMAL } \\
\text { (detik) }\end{array}$ & $\begin{array}{c}\text { ALLOW } \\
\text { ENCE } \\
(\boldsymbol{\%})\end{array}$ & $\begin{array}{c}\text { W.STAN } \\
\text { DART } \\
\text { (detik) }\end{array}$ \\
\hline $0-19$ & 31.63 & 0.15 & 37.21 \\
\hline $0-20$ & 32.08 & 0.15 & 37.74 \\
\hline $0-21$ & 45.54 & 0.15 & 53.58 \\
\hline $0-22$ & 69.48 & 0.15 & 81.74 \\
\hline $0-23$ & 48.08 & 0.15 & 56.56 \\
\hline $0-24$ & 23.2 & 0.15 & 27.29 \\
\hline $1-02$ & 20.28 & 0.15 & 23.86 \\
\hline $0-25$ & 30.98 & 0.15 & 36.45 \\
\hline $0-26$ & 23.09 & 0.15 & 27.16 \\
\hline $0-27$ & 23.96 & 0.15 & 28.19 \\
\hline $0-28$ & 18.09 & 0.15 & 21.28 \\
\hline $0-29$ & 45.94 & 0.15 & 54.05 \\
\hline $0-30$ & 23.32 & 0.15 & 27.43 \\
\hline $0-31$ & 48.48 & 0.15 & 57.03 \\
\hline $1-03$ & 16.59 & 0.15 & 19.52 \\
\hline $0-32$ & 10.90 & 0.15 & 12.82 \\
\hline
\end{tabular}

\section{Analisa kondisi Lintasan Produksi (stasiun}

\section{kerja) awal}

Analisa kondisi awal dilakukan dengan menentukan siklus yang dari pengelompokan elemen - elemen kerja ke dalam stasiun kerja awal. Dari hasil pengelompokan elemen elemen kerja kedalam stasiun kerja diperoleh waktu stasiun kerja yang terbesar yang dianggap sebagai waktu siklus dari stasiun kerja awal.

Tabel 4. Penempatan Operasi kedalam Stasiun kerja Awal

\begin{tabular}{|c|c|c|c|}
\hline $\begin{array}{l}\text { STASIUN } \\
\text { KEJA }\end{array}$ & RANKING & $\begin{array}{c}\text { NO. } \\
\text { OPERASI }\end{array}$ & $\begin{array}{c}\text { W. } \\
\text { STANDART }\end{array}$ \\
\hline 1 & 1 & $0-01$ & 40.12 \\
\hline 2 & 2 & $0-02$ & 79.63 \\
\hline 3 & 3 & $0-03$ & 111.57 \\
\hline 4 & 4 & $0-04$ & 68.09 \\
\hline 5 & 5 & $0-05$ & 78.22 \\
\hline 6 & 6 & $0-06$ & 41.72 \\
\hline 7 & 7 & $0-07$ & 16.65 \\
\hline 8 & 8 & $0-08$ & 38.62 \\
\hline 9 & 9 & $0-09$ & 19.54 \\
\hline 10 & 10 & $0-10$ & 40.26 \\
\hline 11 & 11 & $0-11$ & 38.95 \\
\hline 12 & 12 & $0-12$ & 110.78 \\
\hline 13 & 13 & $0-13$ & 77.96 \\
\hline 14 & 14 & $0-14$ & 19.68 \\
\hline 15 & 15 & $0-15$ & 27.70 \\
\hline 16 & 16 & $0-16$ & 9.03 \\
\hline 17 & 17 & $0-17$ & 16.65 \\
\hline 18 & 18 & $0-18$ & 16.50 \\
\hline 19 & 19 & $0-19$ & 37.21 \\
\hline 20 & 20 & $0-20$ & 37.74 \\
\hline
\end{tabular}

\begin{tabular}{|c|c|c|c|}
\hline $\begin{array}{c}\text { STASIUN } \\
\text { KEJA }\end{array}$ & RANKING & $\begin{array}{c}\text { NO. } \\
\text { OPERASI }\end{array}$ & $\begin{array}{c}\text { W. } \\
\text { STANDART }\end{array}$ \\
\hline 21 & 21 & $0-21$ & 53.58 \\
\hline 22 & 22 & $0-22$ & 81.74 \\
\hline 23 & 23 & $0-23$ & 56.56 \\
\hline 24 & 24 & $0-24$ & 27.29 \\
\hline 25 & 25 & $0-25$ & 36.45 \\
\hline 26 & 26 & $0-26$ & 27.16 \\
\hline 27 & 27 & $0-27$ & 28.19 \\
\hline 28 & 28 & $0-28$ & 21.28 \\
\hline 29 & 29 & $0-29$ & 54.05 \\
\hline 30 & 30 & $0-30$ & 27.43 \\
\hline 31 & 31 & $0-31$ & 57.03 \\
\hline 32 & 32 & $0-32$ & 12.82 \\
\hline
\end{tabular}

Dari hasil pengelompokan elemen kerja diatas dapat diketahui waktu siklus terbesar dari stasiun kerja adalah 111.57 detik, sehingga balance delay awal adalah sebagai berikut:

- Balance delay awal

$$
\begin{aligned}
D & =\left[\frac{n \cdot c-\sum t_{i}}{n \cdot c}\right] x 100 \% \\
D & =\left[\frac{(32 x 111.57)-1410.2}{32 \times 111.57}\right] \times 100 \% \\
& =60.56 \%
\end{aligned}
$$

๑ Effesiensi sistem awal

$$
\begin{aligned}
\pi & =100 \%-60.56 \\
& =39.44 \%
\end{aligned}
$$

○ Output Standart

$$
\begin{aligned}
O s & =\frac{1}{W s} \\
O S & =\frac{1}{111.57} \\
& =0.0089 / \text { detik } \\
& =32.04=32 / \mathrm{jam} \\
& =7 \times 32.04 / \mathrm{hari} \\
& =224.04 / 2 \text { pasang perhari } \\
& =112 \text { pasang } / \text { hari }
\end{aligned}
$$




\section{Perencanaan Keseimbangan lintasan dengan metode Rank Positional Weight}

Dengan menggunakan waktu siklus ditentukan sendiri (dengan mengadakan beberapa kali percobaan diantaranya dengan waktu siklus 100,150 dan 160 detik), diperoleh waktu siklus yang memiliki balance dellay yang nilainya kecil yaitu pada waktu siklus 150 detik menghasilkan balance dellay sebesar 5.99\%.

Adapun hasil dari perencanaan keseimbangan lintasan berupa pengelompokan elemen-elemen kerja kedalam stasiun-stasiun kerja baru dengan waktu siklus 150 detik, yaitu sebagai berikut :

\section{Tabel 5. Pengelompokan elemen kerja} kedalam stasiun kerja

\begin{tabular}{|c|c|c|}
\hline $\begin{array}{l}\text { Stas } \\
\text { kerja }\end{array}$ & $\begin{array}{c}\text { NO } \\
\text { OPERASI }\end{array}$ & OPERASI \\
\hline 1 & $\begin{array}{l}0-01 \\
0-02 \\
0-14\end{array}$ & $\begin{array}{l}\text { Pengemalan } \\
\text { Pemotongan Bahan Kulit sesuai } \\
\text { dengan pola } \\
\text { Pengemalan in sole }\end{array}$ \\
\hline 2 & $\begin{array}{l}0-03 \\
0-19\end{array}$ & $\begin{array}{l}\text { Penyesetan } \\
\text { Pencetakan lasting }\end{array}$ \\
\hline 3 & $\begin{array}{l}0-04 \\
0-05\end{array}$ & $\begin{array}{l}\text { Pengeleman hasil seset } \\
\text { Penglipatan bagian seset }\end{array}$ \\
\hline 4 & $\begin{array}{l}0-06 \\
0-07 \\
0-08 \\
0-09 \\
0-15\end{array}$ & $\begin{array}{l}\text { Trap model } \\
\text { Pcngcmalan (linning dan kcras) } \\
\text { Memotong lining (linning dan } \\
\text { keras) sesuai dengan pola } \\
\text { Memberi lem pada lining yang } \\
\text { akan diseset } \\
\text { Lem tepian kap }\end{array}$ \\
\hline 5 & $\begin{array}{l}0-10 \\
0-20 \\
0-11 \\
0-28 \\
0-16\end{array}$ & $\begin{array}{l}\text { Pemasangan lining } \\
\text { Amplas te[ian hasil lasting } \\
\text { Pengetrapan } \\
\text { Pengemalan sok lining } \\
\text { Pemotongan in sole }\end{array}$ \\
\hline 6 & $\begin{array}{l}0-21 \\
0-22 \\
\end{array}$ & $\begin{array}{l}\text { Amplas out sole } \\
\text { Pengeleman out sole }\end{array}$ \\
\hline 7 & $\begin{array}{l}0-12 \\
0-17 \\
0-18 \\
\end{array}$ & $\begin{array}{l}\text { Penjahitan } \\
\text { Pengeleman In Sole } \\
\text { Pemasangan In Sole }\end{array}$ \\
\hline 8 & $\begin{array}{l}0-23 \\
0-13\end{array}$ & $\begin{array}{l}\text { Pemasangan Out Sole } \\
\text { Diberi besi (lubang tali) }\end{array}$ \\
\hline 9 & $\begin{array}{l}0-29 \\
0-24 \\
0-25 \\
0-30\end{array}$ & $\begin{array}{l}\text { Pemotongan bahan sok linning } \\
\text { Pengepresan } \\
\text { Pembersihan lem dan noda } \\
\text { Pengeleman bahan sok lining }\end{array}$ \\
\hline 10 & $\begin{array}{l}0-31 \\
0-26 \\
0-27 \\
0-32 \\
\end{array}$ & $\begin{array}{l}\text { Pemasangan sok lining } \\
\text { Penyemiran } \\
\text { Pengeleman In Sole dalam } \\
\text { Pengepakan }\end{array}$ \\
\hline
\end{tabular}

\section{Perbandingan Sistem Sebelum Dan Sesudah} Penerapan Line Balancing

\section{Pengelompokan Elemen Kerja Kedalam Stasiun Kerja}

Pada pengelompokan elemen kerja kedalam stasiun kerja untuk kondisi awal menghasilkan 32 stasiun kerja, dalam satu stasiun kerja dikerjakan oleh 1operator (32 Stasiun kerja $=32$ Operator), serta 112 pasang sepatu sebagai outputnya. Sedangkan setelah penerapan Line Balancing menghasilkan 10 stasiun kerja serta 84 pasang sepatu sebagai outputnya, Karena masih dibawah kondisi awal dan juga tenaga kerja mengalami banyak pengurangan, maka untuk menambah Out put maka tiap eleman kerja ditambah 1 Operator, berati jumlah Operator menjadi 20 Operator dan Outputnya $=168$ pasang perhari.

Dari keterangan diatas sudah jelas bahwa pengelompokan sejumlah operasi kedalam stasiun kerja baru dengan waktu siklus 150 akan menyeimbangkan beban kerja diantara proses operasi, sehingga balance delay (waktu mwnganggur) akan semakin minimum yang berarti pula bahwa waktu penyelesaian untuk pembuatan produk tersebut akan semakin singkat, sehingga permintaan dapat di penuhi dengan baik (sebelum waktu yang ditetapkan).

2. Perincian Tenaga Kerja Dan Upah Tenaga Kerja.

Sebelum perencanaan Linenbalancing (kondisi awal).

Jumlah tenaga kerja $\quad=32$ orang

Upah $\quad=$ Rp. $15.000 /$ hari

Total biaya $($ tenaga kerja $)=$ Rp. $480.000 /$ hari 
Setelah perencanaan keseimbangan lintasan.

Jumlah tenaga kerja $\quad=20$ orang Upah $=$ Rp. $15.000 /$ hari

Total biaya $($ tenaga kerja) $=$ Rp. $300.000 /$ hari

Penggunaan biaya setelah line balancing semakin murah karena hanya menggunakan 20 tenaga kerja sedangkan sebelum line balancing menggunakan 32 tenaga kerja.

3. Out-put yang dihasilkan dan tingkat permintaan produk.

Permintaan untuk produk ini cukup banyak dan perusahaan sering mendapatkan permintaan/order akan produk ini, sedangkan out-put untuk kondisi awal sebanyak 112 pasang sepatu perhari dan tingkat permintaan sebesar 5500 pasang perbulan, maka untuk pembuatan produk ini dapat diselesaikan dalam waktu 49 hari. sedangkan setelah perencanaan Line balancing output yang dihasilkan sebanyak 168 pasang sepatu perhari dan tingkat permintaan sebesar 5500 pasang sepatu perbulan, maka untuk pembuatan produk ini dapat diselesaikan dalam waktu 33 hari.

\section{Balance dellay}

Pada kondisi awal diperoleh Balance delay sebesar $60.56 \%$, sedangkan Balance delay sesudah perencanaan line balancing adalah sebesar $5.99 \%$, dari data tersebut maka dapat disimpulkan bahwa ada penurunan Balance delay sebesar $54.57 \%$, dan artinya bahwa setelah perencanaan Line balancing mengalami tingkat keseimbangan yang lebih baik dari keadaan sebelumnya atau dengan kata lain lintasan produksi menjadi lebih lancar, karena waktu dari setiap elemen semakin merata.

\section{Effisiensi Sistem}

Pada kondisi awal diperoleh effisiensi sistem sebesar $39.44 \%$, sedangkan effisiensi sistem setelah perencanaan Line balancing sebesar $94.01 \%$, dari data tersebut maka dapat disimpulkan bahwa ada peningkatan effisiensi sebesar $51.97 \%$.

\section{KESIMPULAN}

Dari hasil analisa yang telah dilakukan terhadap adanya perencanaan keseimbangan lintasan tersebut diatas, maka dapat disimpulkan:

1. Setelah dilakukan perencanaan Line Balancing, maka didapatkan pengelompokan elemen-elemen kerja kedalam stasiun kerja baru, yang menghasilkan 10 stasiun kerja, untuk lebih jelasnya lihat tabel berikut:

\section{Tabel 6. Pengelompokan elemen kerja kedalam stasiun kerja}

\begin{tabular}{|c|c|c|}
\hline $\begin{array}{l}\text { STASIUN } \\
\text { KERJA }\end{array}$ & $\begin{array}{c}\text { NO } \\
\text { OPERASI }\end{array}$ & OPERASI \\
\hline 1 & $\begin{array}{l}0-01 \\
0-02 \\
0-14\end{array}$ & $\begin{array}{l}\text { Pengemalan } \\
\text { Pemotongan Bahan Kulit } \\
\text { sesuai dengan pola } \\
\text { Pengemalan in sole }\end{array}$ \\
\hline 2 & $\begin{array}{r}0-03 \\
0-19\end{array}$ & $\begin{array}{l}\text { Penyesetan } \\
\text { Pencetakan lasting }\end{array}$ \\
\hline 3 & $\begin{array}{l}0-04 \\
0-05\end{array}$ & $\begin{array}{l}\text { Pengeleman hasil seset } \\
\text { Penglipatan bagian seset }\end{array}$ \\
\hline 4 & $\begin{array}{l}0-06 \\
0-07 \\
0-08 \\
0-09 \\
0-15\end{array}$ & $\begin{array}{l}\text { Trap model } \\
\text { Pengemalan (linning dan keras) } \\
\text { Memotong lining (linning dan } \\
\text { keras) sesuai dengan pola } \\
\text { Memberi lem pada lining yang } \\
\text { akan diseset } \\
\text { Lem tepian kap }\end{array}$ \\
\hline 5 & $\begin{array}{l}0-10 \\
0-20 \\
0-11 \\
0-28 \\
0-16 \\
\end{array}$ & $\begin{array}{l}\text { Pemasangan lining } \\
\text { Amplas te[ian hasil lasting } \\
\text { Pengetrapan } \\
\text { Pengemalan sok lining } \\
\text { Pemotongan in sole }\end{array}$ \\
\hline 6 & $\begin{array}{r}0-21 \\
0-22 \\
\end{array}$ & $\begin{array}{l}\text { Amplas out sole } \\
\text { Pengeleman out sole }\end{array}$ \\
\hline 7 & $\begin{array}{r}0-12 \\
0-17 \\
0-18\end{array}$ & $\begin{array}{l}\text { Penjahitan } \\
\text { Pengeleman In Sole } \\
\text { Pemasangan In Sole }\end{array}$ \\
\hline
\end{tabular}




\begin{tabular}{|c|c|l|}
\hline $\begin{array}{c}\text { STASIUN } \\
\text { KERJA }\end{array}$ & $\begin{array}{c}\text { NO } \\
\text { OPERASI }\end{array}$ & \multicolumn{1}{|c|}{ OPERASI } \\
\hline 8 & $0-23$ & Pemasangan Out Sole \\
& $0-13$ & Diberi besi (lubang tali) \\
\hline 9 & $0-29$ & Pemotongan bahan sok linning \\
& $0-24$ & Pengepresan \\
& $0-25$ & Pembersihan lem dan noda \\
& $0-30$ & Pengeleman bahan sok lining \\
\hline 10 & $0-31$ & Pemasangan sok lining \\
& $0-26$ & Penyemiran \\
& $0-27$ & Pengeleman In Sole dalam \\
& $0-32$ & Pengepakan \\
\hline
\end{tabular}

2. Setelah dilakukan perencanaan Line Balancing, maka diperoleh balance dellay yang minimal yaitu $5.99 \%$ yang lebih rendah bila dibandingkan dengan keadaan awalnya yaitu $60.56 \%$. serta Effisiensi sebesar $94.01 \%$ yang merupakan Efisiensi terbaik bila di bandingkan dengan keadaan semula (keadaan awal) yaitu sebesar $39.44 \%$.

\section{DAFTAR PUSTAKA}

Suta laksana, Iftikar z, Ruhana anggu wisastra, Janti h, Tjokra atmaja, "Teknik Tata Cara Kerja", Laboratorium Tata Cara Kerja dan Ergonomi Departemen ITB, Bandung, 1979.

Wignyosoebroto, Sritomo, "Teknik Tata Cara

Kerja dan pengukuran kerja", Penerbit

Guna Widya, Jakarta, 1992.

- El Sayet. A, and Tomas O Baucher, "Analisa

and Control Of Produktion Sistem",

Second Edition, Departemen Of Industrial

Engeneering College of Engeenering

Recrers University, new jersey, 1989.

Sudjana,"Metode Statika", Edisi kelima,

Penerbit Tarsito Bandung, 1979. 